\title{
Numerical Analysis of the Relationship Between Mycobacterium, Rhodochrous Group, and Nocardia by Use of Hypothetical Median Organisms
}

\author{
M. TSUKAMURA \\ The National Sanatorium Chubu Chest Hospital, Obu, Aichi, Japan 474
}

\begin{abstract}
A total of 1,054 strains was allocated to species of the genera Mycobacterium, Nocardia, and Gordona (the rhodochrous group) on the basis of 88 characters, and hypothetical median organisms (HMOs) were derived for each species. Numerical analysis was carried out, treating these HMOs as operational taxonomic units. The dendrogram obtained showed that strains received as members of the rhodochrous group, including "Mycobacterium" rhodochrous, and strains named previously by the present author as Gordona, constituted a taxon comparable to the genus Nocardia. The analysis showed two separable groups at a 70\% $M$ value (matching coefficient) level. One consisted of slowly growing mycobacteria (Mycobacterium subgenus Mycobacterium Tsukamura) and the second consisted of rapidly growing mycobacteria (Mycobacterium subgenus Mycomycobacterium Tsukamura), the genus Gordona (including the rhodochrous group) and Nocardia. Diagrammatic representation of the taxonomic relationships by taxonomic distances showed the same result. Four taxa, which might be regarded as separate genera, separated at higher $M$ values. These included the slowly growing mycobacteria, the rapidly growing mycobacteria, the genus Gordona (rhodochrous group), and the genus Nocardia, respectively. The slowly growing mycobacteria seem to be only distantly related to the other three, which bear a close relationship with each other.
\end{abstract}

Gordon and Mihm (5) named some strains received as nocardiae "Mycobacterium" rhodochrous. Later, Gordon (4) regarded this taxon as an intermediate between the genera Mycobacterium and Nocardia. Tsukamura (16) isolated a number of slightly acid-fast organisms from sputa of patients with lung disease and from soil and classified them into three species of a new genus, Gordona. Thereafter, strains received as $M$. rhodochrous were shown to belong to the same genus, and the majority of the strains received were identified as belonging to the species Gordona rhodochroa of this genus (17). Independently of these studies, Goodfellow (2) and Goodfellow et al. (3) reported that strains of $M$. rhodochrous could be differentiated from nocardiae and rapidly growing mycobacteria, respectively.

Previously, studies on the relationships between rapidly growing mycobacteria, Gordona (rhodochrous group), and Nocardia were carried out by Tsukamura $(15,16,18)$. However, he did not consider the slowly growing mycobacteria. The present study is concerned with the relationships between Mycobacterium, including slowly growing mycobacteria, the rhodochrous group, and Nocardia.

\section{MATERIALS AND METHODS}

A total of 1,054 strains of Mycobacterium, the rhodochrous group, and Nocardia was allocated to species by comparing their characters with those of reference strains (14).

The characters tested are listed in Table 1. Most of the methods used were described previously (11$14,16,20)$. Amidase activity, catalase activity, Tween hydrolysis activity, esterase activity, $\beta$-galactosidase activity, and acid phosphatase activity were tested by the methods of Bönicke (1), Kubica et al. (8), Wayne et al. (23), Käppler (6), Tsukamura (19), and Tsukamura et al. (22), respectively. Of these characters, 85 were effective for differentiating the strains. Only three characters (growth at $37 \mathrm{C}$, permanent mycelium, and weak acid fastness) were ineffective, showing positive or negative matches in all test strains.

The species identified are listed in Table 2.

In employing numerical methods to compare the species, comparisons were made between hypothetical median organisms (HMOs), one HMO first being derived, using the method of Liston et al. (9), for each species by analysis of the characters of the strains which had been allocated to it.

Matching coefficients ( $M$ values) were calculated by the following equation: $M$ value $=\left[n_{s} /\left(n_{s}+n_{d}\right)\right]$ $\times 100 \%$, where $n_{s}$ is the number of characters which show similar code symbols $(++$ or --$)$ and $n_{d}$ is 
TABLE 1. List of characters used for tests

Acid fastness (strong)

Acid fastness (weak or partial)

Shape (rod form)

Cord formation

Fragmenting mycelium

Permanent mycelium

Colony (rough)

Colony (pigment)

Photochromogenicity

Rapid growth (growth at 3 days)

Tolerance to nitrite $(0.1 \%)$

Tolerance to picric acid $(0.2 \%)$

Rifampin $(25 \mu \mathrm{g} / \mathrm{ml})$

PAS $(0.2 \%)$ tolerance

$\mathrm{NH}_{2} \mathrm{OH} \cdot \mathrm{HCl}(0.125 \mathrm{mg} / \mathrm{ml})$

$\mathrm{NH}_{2} \mathrm{OH} \cdot \mathrm{HCl}(0.25 \mathrm{mg} / \mathrm{ml})$

$\mathrm{NH}_{2} \mathrm{OH} \cdot \mathrm{HCl}(0.5 \mathrm{mg} / \mathrm{ml})$

$\mathrm{TCH}(10 \mu \mathrm{g} / \mathrm{ml})$

Tolerance to salicylate $(0.5 \mathrm{mg} / \mathrm{ml})$

$p$-Nitrobenzoic acid $(0.5 \mathrm{mg} / \mathrm{ml})$

Niacin production

Tween hydrolysis ( 7 days)

Tween hydrolysis (14 days)

$\alpha$-Esterase

$\beta$-Esterase

Acid phosphatase

Catalase (foam more than $45 \mathrm{~mm}$ )

$\beta$-Galactosidase

Nitrate reduction

3-day arylsulfatase

2 -week arylsulfatase

Salicylate degradation

PAS degradation

Acetamidase

Benzamidase

Urease

Isonicotinamidase

Nicotinamidase

Pyrazinamidase

Salicylamidase

Allantoinase

Succinamidase

Growth at $28 \mathrm{C}$

Growth at $37 \mathrm{C}$
Growth at $45 \mathrm{C}$

Growth at $52 \mathrm{C}$

Glucose (C source)

Mannose (C source)

Sucrose (C source)

$n$-Propanol (C source)

n-Butanol (C source)

iso-Butanol (C source)

Propylene glycol (C source)

Galactose (C source)

Arabinose (C source)

Xylose (C source)

Rhamnose (C source)

Trehalose (C source)

Inositol (C source)

Mannitol (C source)

Sorbitol (C source)

Acetate (C source)

Citrate (C source)

Succinate (C source)

Malate (C source)

Pyruvate (C source)

Benzoate (C source)

Malonate (C source)

Fumarate (C source)

Acid from glucose

Acid from mannose

Glucose as C source (glutamate-N)

Acetate as C source (glutamate- $\mathrm{N}$ )

Succinate as C source (glutamate-N)

Pyruvate as C source (glutamate-N)

Glycerol as C source (glutamate-N)

Glutamate as N-C source

Serine as N-C source

Glucosamine as $\mathrm{N}-\mathrm{C}$ source

Acetamide as $\mathrm{N}-\mathrm{C}$ source

Benzamide as $\mathrm{N}-\mathrm{C}$ source

Monoethanolamine as N-C source

Trimethylene diamine as $\mathrm{N}-\mathrm{C}$ source

Benzamide as $\mathrm{N}$ source

Nicotinamide as $\mathrm{N}$ source

Nitrate ( $\mathrm{N}$ source)

Nitrite ( $\mathrm{N}$ source)

Ethambutol tolerance $(5 \mu \mathrm{g} / \mathrm{ml})$ the number of characters which show different code symbols $(+-)$. Clustering was made by the singlelinkage method.

Relationships between the taxa were estimated by taxonomic distance (10). The taxonomic distance (d) was expressed by the following equation: $d=$ $(100-x) / x$, where $x$ is a mean $M$ value (\%) between the taxa. The dimension of a taxon was expressed by a sphere or circle, the radius $(r)$ of which was calculated by the following equation: $r=(100-y) / y$, where $y$ is a mean $M$ value (\%) within a taxon.

\section{RESULTS}

Dendrogram. A dendrogram was prepared by comparing the HMOs (Fig. 1). The species of the genus Nocardia formed a cluster at the $84 \%$ level, and the species of Gordona formed a cluster at the $85 \%$ level. The cluster of Gordona was linked with several rapidly growing mycobacteria, $M$. aichiense, $M$. chubuense, $M$. tokaiense, $M$. aurum, $M$. neoaurum, $M$. parafortuitum, $M$. rhodesiae, and $M$. obuense, at the $85 \%$ level. These rapidly growing mycobacteria are scotochromogenic.

Rapidly growing mycobacteria (Table 2 ) were placed in dispersed positions. Slowly growing mycobacteria (Table 2) formed a distinct cluster at the $86 \%$ level, with the exception of $M$. tuberculosis and $M$. bovis. On the basis of the data presented, these two organisms, $M$. tuberculosis and $M$. bovis, were more sharply separated from the other slowly growing mycobacteria 
TABLE 2. List of species tested

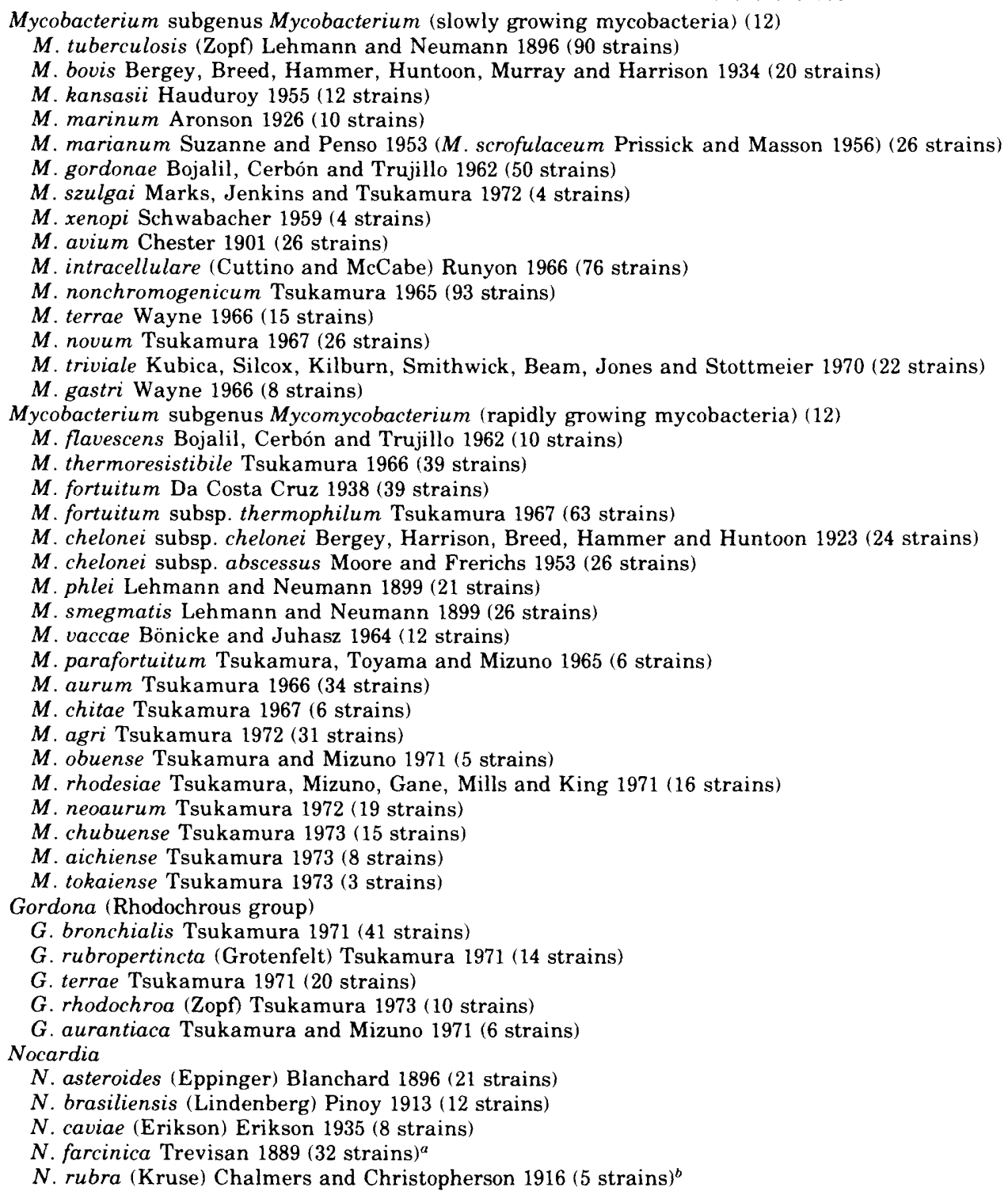

a This species was separated from $N$. asteroides by Tsukamura (14), who regarded it as a distinct species. The name is based on the fact that the group contains $N$. farcinica ATCC 3318.

${ }^{\circ}$ Contains strains collected by Tsukamura (14) with different species names.

than the Gordona organisms from the nocardiae, etc.

Nocardia rubra was not incorporated into the cluster of Nocardia but into the cluster of Gordona. Though this organism shows fragmenting (temporary) mycelium, and in this point differs from other hitherto described Gordona organisms, it is elsewhere proposed that it be transferred to the genus Gordona (21).
Mycobacterium smegmatis was not incorporated into any cluster at a level above $79 \%$. It was linked to all the other strains at the $78 \%$ level as was the cluster consisting of $M$. bovis and $M$. tuberculosis. The $M$ value between $M$. bovis and $M$. smegmatis was, however, only $23 \%$.

$M$ value table. A diagrammatic representation of the $M$ values obtained by comparing the 


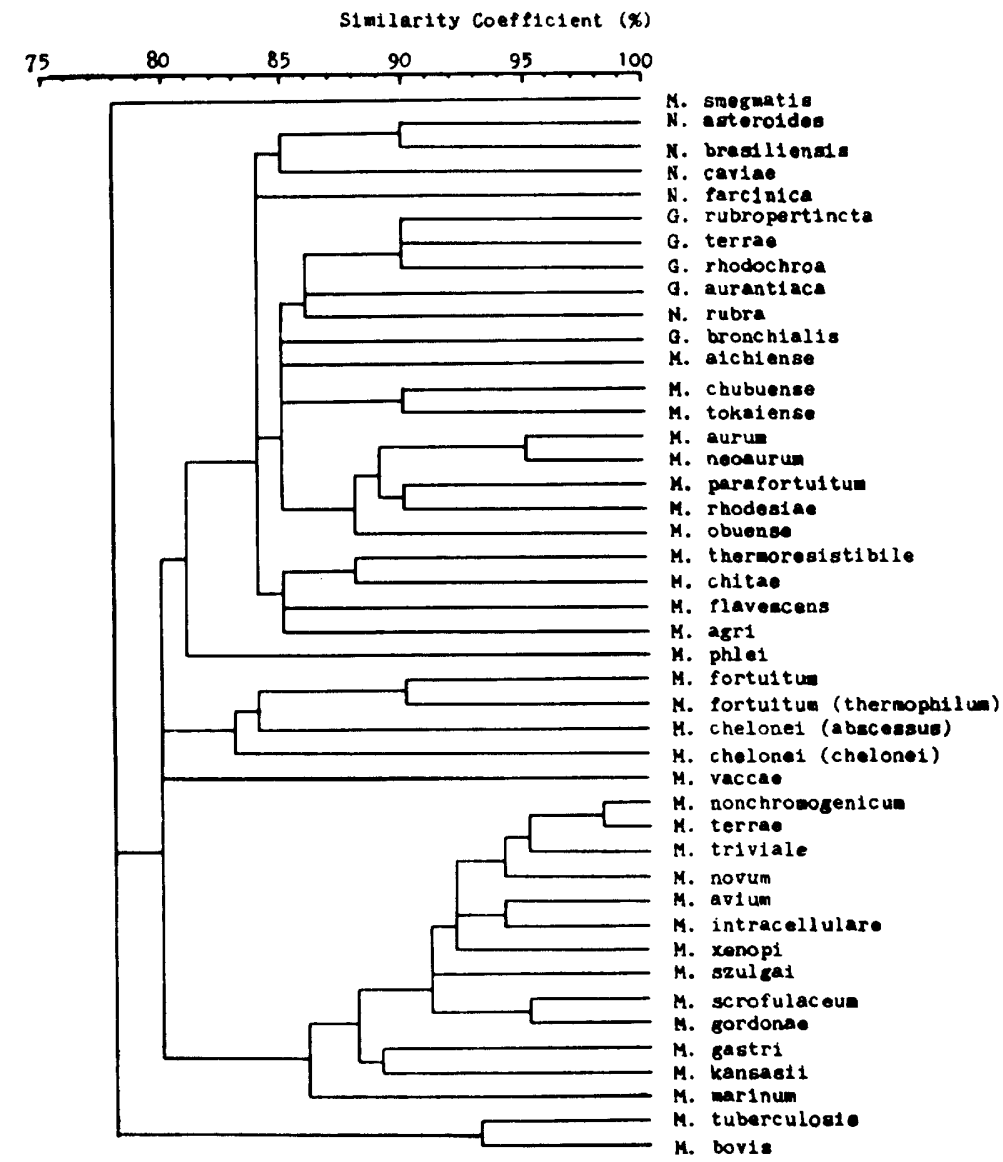

FIG. 1. Dendogram showing the relationship of the HMOs of the species studied.

HMOs is shown in Fig. 2. It reflects the relationships noted from the dendrogram and dramatically emphasizes the isolation of the $M$. bovis, $M$. tuberculosis cluster from all other groups even at the $70 \%$ level.

Taxonomic distances. Taxonomic distances between slowly growing mycobacteria ( $M y c o-$ bacterium subgenus $M y c o b a c t e r i u m)$, rapidly growing mycobacteria (Mycobacterium subgenus Mycomycobacterium), genus Nocardia, and the rhodochrous group (genus Gordona) are shown in Fig. 3.

The results confirm that slowly growing mycobacteria are distinctly separate from the other three taxa: rapidly growing mycobacteria, Gordona, and Nocardia. The latter three taxa are near each other. The characters useful for distinguishing these taxa are shown in Table 3 .

\section{IISCUSSION}

Previously, Tsukamura (12) proposed that the genus Mycobacterium be divided into two subgenera, Mycobacterium and Mycomycobacterium. These subgenera corresponded approximately to slowly growing mycobacteria and rapidly growing mycobacteria, respectively. The subgenera were separated from each other not only by growth rate but also by several other characters $(11,12,15)$.

In the present study, it was confirmed that slowly growing mycobacteria distinctly differ from rapidly growing mycobacteria. Rapidly growing mycobacteria appeared to be similar to Gordona and Nocardia.

The taxonomic status of Gordona is considered to be equivalent to that of Nocardia. The recognition of two subgenera of the genus $M y c o-$ bacterium is also strengthened by the data shown in the present study. Should the subgenus Mycomycobacterium Tsukamura be raised to the status of a genus, $M$. phlei may be appropriate as the type species. Previously, Tsukamura (15) proposed $M$. smegmatis as the type species of the subgenus Mycomycobacterium. In light of the results of the present study, 

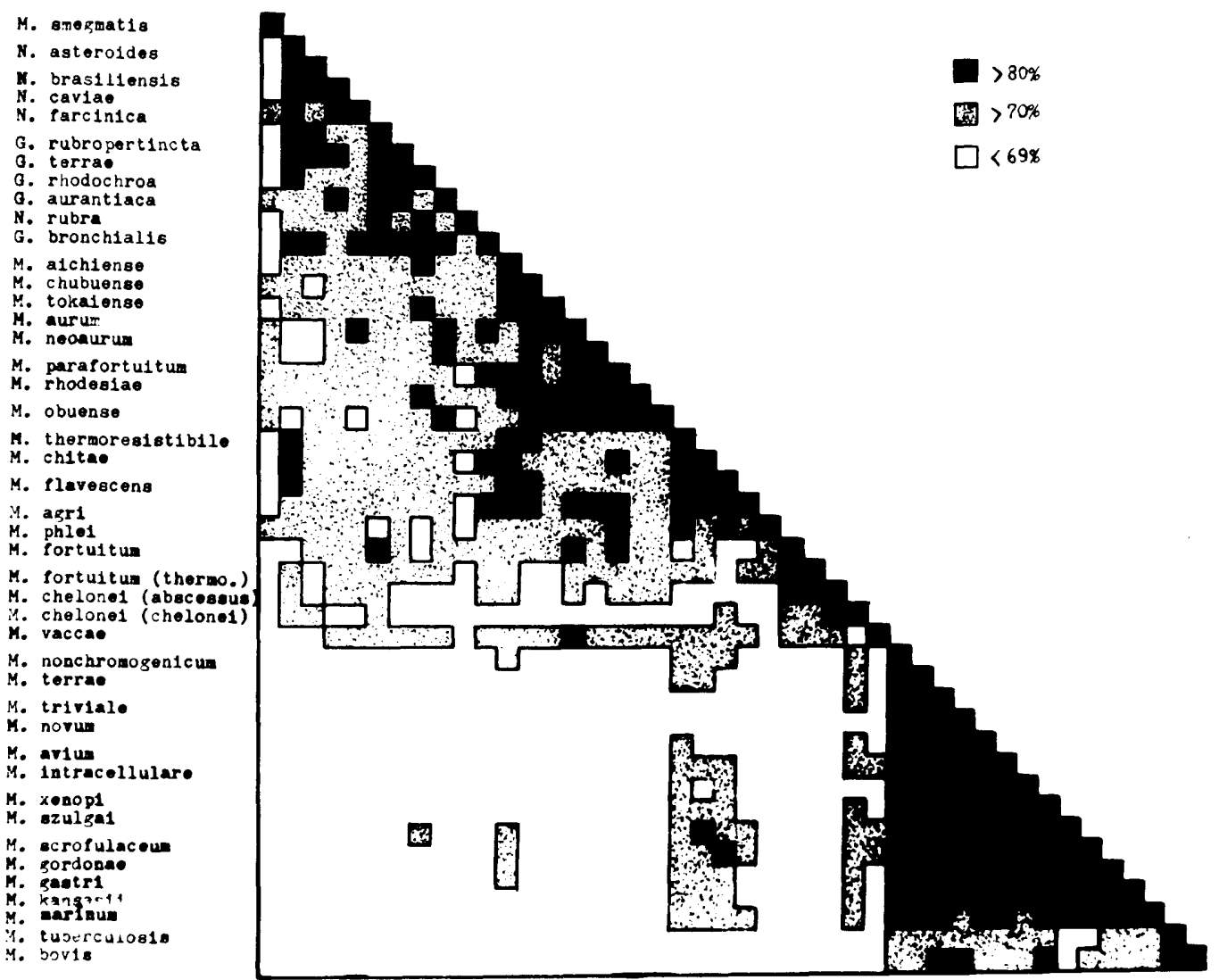

FIG. 2. Diagrammatic representation of $M$-value table.

however, $M$. smegmatis seems inappropriate as the type species.

Some slight changes in the affinities between taxa are seen in the present study in contrast to the data of previous studies. These are probably due to difference in the characters used for study. In the present study, the number of enzyme tests was increased and the number of tests belonging to the same kind was decreased. For example, previously, 10 tests on acid formation from various carbohydrates were used, but only two tests (acid from glucose and acid from mannose) were used in the present study. Previously, 11 tests on the utilization of nitrogen compounds were used, whereas only 4 tests were used in the present study. Furthermore, a few tests which in the past gave relatively large experimental errors were omitted. These modifications of the set of characters were undertaken with the expected result of a sharper separation between taxa.

It may be surprising that $M$. smegmatis has shown such a low affinity to other taxa containing mycobacteria. However, the same finding had been obtained previously in our study (laboratory $\mathrm{H}$ ), which was included in the cooperative study of the International Working Group on Mycobacterial Taxonomy (7). It is believed that the greater the number of characters which are effective for separation between strains (or taxa), the sharper will be the separation. M. smegmatis is believed to have been distinguished from others in the present study by the presence of many characters effective for separation. The organism is believed to occupy a special position among mycobacteria.

In the present study, $N$. rubra was incorporated into the cluster of the Gordona organisms. In fact, mean $M$ values of this organism to Gordona, Nocardia, rapidly growing mycobacteria, and slowly growing mycobacteria were $80.0 \pm 4.3 \%(n=5), 76.1 \pm 2.9 \%(n=4)$, $68.5 \pm 4.1 \%(n=19)$, and $54.0 \pm 4.8 \%(n=15)$, respectively, where $n$ is the number of $M$ values. The similarity to the genus Gordona was the highest. Gordon and Mihm (5) included a strain of $N$. rubra (strain McClung-1) in $M$. rhodochrous. The finding of the present study 


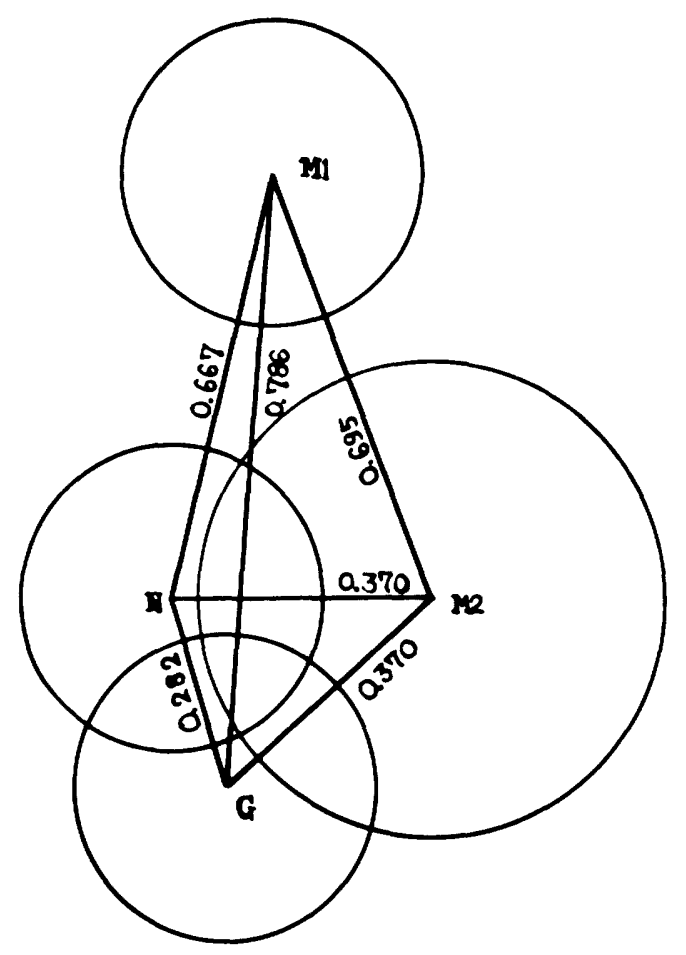

FIG. 3. Relationships between the taxa expressed by taxonomic distances. Abbreviations: M1, Mycobacterium subgenus Mycobacterium (slowly growing mycobacteria); M2, Mycobacterium subgenus Mycomycobacterium (rapidly growing mycobacteria); $G$, Gordona; $N$, Nocardia. The relationships between the taxa are shown by taxonomic distances, and extent of a taxon is expressed by the radius of a sphere. Nocardia rubra is incorporated into the genus Gordona as Gordona.

TABLE 3. Characters useful for distinguishing between Mycobacterium subgenus Mycobacterium, Mycobacterium subgenus Mycomycobacterium, Gordona, and Nocardia

\begin{tabular}{|c|c|c|c|c|}
\hline \multirow[b]{2}{*}{ Character } & \multicolumn{4}{|c|}{ HMOs (species) showing positive reaction (\%) } \\
\hline & Mycobacterium & $\begin{array}{l}\text { Mycomycobac- } \\
\text { terium }\end{array}$ & Gordona & Nocardia \\
\hline Strong acid fastness & 100 & 100 & 0 & 0 \\
\hline Fragmenting mycelium & 0 & 0 & 17 & 100 \\
\hline Growth at 3 days & 7 & 100 & 100 & 100 \\
\hline $0.1 \% \mathrm{NaNO}_{2}$-Sauton agar & 0 & 100 & 100 & 100 \\
\hline $0.2 \%$ Picric acid-Sauton agar & 0 & 95 & 100 & 100 \\
\hline$\beta$-Galactosidase & 0 & 21 & 0 & 100 \\
\hline Nitrate reduction & 27 & 53 & 83 & 25 \\
\hline 2-Week arylsulfatase & 73 & 89 & 0 & 0 \\
\hline Glucose as C source & 27 & 100 & 100 & 100 \\
\hline Mannose as C source & 0 & 89 & 100 & 50 \\
\hline Sucrose as $\mathrm{C}$ source & 0 & 32 & 100 & 0 \\
\hline$n$-Butanol as C source & 20 & 89 & 100 & 100 \\
\hline Succinate as C source & 0 & 89 & 100 & 100 \\
\hline Malate as C source & 0 & 89 & 100 & 100 \\
\hline Fumarate as $\mathrm{C}$ source & 0 & 84 & 100 & 100 \\
\hline Acid from glucose & 0 & 89 & 100 & 100 \\
\hline Acid from mannose & 0 & 74 & 83 & 0 \\
\hline Glutamate as $\mathrm{N}$ and $\mathrm{C}$ source & 0 & 100 & 100 & 100 \\
\hline $\begin{array}{l}\text { Trimethylene diamine as } \mathrm{N} \\
\text { and } \mathrm{C} \text { source }\end{array}$ & 0 & 58 & 0 & 0 \\
\hline $\mathrm{NaNO}_{3}$ as $\mathrm{N}$ source (glucose-C) & 0 & 84 & 100 & 100 \\
\hline Rough colonies & 40 & 26 & 100 & 100 \\
\hline Propylene glycol as C source & 0 & 58 & 83 & 25 \\
\hline No. of HMOs & 15 & 19 & 6 & 4 \\
\hline
\end{tabular}


supported their finding. A proposal on the taxonomic status of $N$. rubra is reported elsewhere in this journal (21).

\section{ACKNOWLEDGMENTS}

I thank S. Mizuno, H. Murata, and T. Oshima for their technical assistance, S. Uchida, Sumitomo Machinery Company, for his kind help in computer studies, and V. B. D. Skerman, Department of Microbiology, University of Queensland, Brisbane, Australia, for his kind revision of the manuscript.

\section{LITERATURE CITED}

1. Bönicke, R. 1962. L'identification des mycobactéries à l'aide de méthodes biochimiques. Bull. Union Int. Tuberc. $32: 13-76$.

2. Goodfellow, M. 1971. Numerical taxonomy of some nocardioform bacteria. J. Gen. Microbiol. 69:33-80.

3. Goodfellow, M., A. Fleming, and M. J. Sackin. 1972. Numerical classification of "Mycobacterium" rhodochrous and Runyon's group IV mycobacteria. Int. J. Syst. Bacteriol. 22:81-98.

4. Gordon, R. E. 1966. Some strains in search of a genusCorynebacterium, Mycobacterium, Nocardia or what? J. Gen. Microbiol. 43:329-343.

5. Gordon, R. E., and J. M. Mihm. 1957. A comparative study of some strains received as nocardiae. J. Bacteriol. 73:15-27.

6. Käppler, W. 1965. Acetyl-Naphthylamin-Esterasen-Aktivität von Mykobacterien. Beitr. Klin. Tuberk. Lungenkr. 130:1-4.

7. Kubica, G. P., I. Baess, R. E. Gordon, P. A. Jenkins, J. B. G. Kwapinski, C. McDurmont, S. R. Pattyn, H. Saito, V. Silcox, J. L. Stanford, K. Takeya, and M. Tsukamura. 1972. A co-operative numerical analysis of rapidly growing mycobacteria. J. Gen. Microbiol. 73:55-70.

8. Kubica, G. P., W. D. Jones, Jr., V. D. Abbott, R. E. Beam, J. O. Kilburn, and J. C. Cater, Jr. 1966. Differential identification of mycobacteria. I. Tests on catalase activity. Am. Rev. Resp. Dis. 94:400-405.

9. Liston, J., W. Wiebe, and R. R. Colwell. 1963. Quantitative approach to the study of bacterial species. $J$.
Bacteriol. 85:1061-1070.

10. Lysenko, O., and P. H. A. Sneath. 1959. The use of models in bacterial classification. J. Gen. Microbiol. 20:284-299.

11. Tsukamura, M. 1966. Adansonian classification of mycobacteria. J. Gen. Microbiol. 45:253-273.

12. Tsukamura, M. 1967. Identification of mycobacteria. Tubercle 48:311-338.

13. Tsukamura, M. 1969. Identification of Group II scotochromogens and Group III nonphotochromogens of mycobacteria. Tubercle 50:51-60.

14. Tsukamura, M. 1969. Numerical taxonomy of the genus Nocardia. J. Gen. Microbiol. 56:265-287.

15. Tsukamura, M. 1970. Relationship between Mycobacterium and Nocardia. Jpn. J. Microbiol. 14:187-195.

16. Tsukamura, M. 1971. Proposal of a new genus, Gordona, for slightly acid-fast organisms occurring in sputa of patients with pulmonary disease and in soil. J. Gen. Microbiol. 68:15-26.

17. Tsukamura, M. 1973. A taxonomic study of strains received as "Mycobacterium" rhodochrous. Description of Gordona rhodochroa (Zopf; Overbeck; Gordon et Mihm) Tsukamura comb. nov. Jpn. J. Microbiol. 17:189-197.

18. Tsukamura, M. 1974. A further numerical taxonomic study of the Rhodochrous group. Jpn. J. Microbiol. 18:37-44.

19. Tsukamura, M. 1974. Differentiation of the Mycobacterium' rhodochrous-group from nocardiae by $\beta$-galactosidase activity. J. Gen. Microbiol. 80:553-555.

20. Tsukamura, M., and S. Mizuno. 1971. Differentiation of Mycobacterium avium and Mycobacterium intracellulare by utilization of butanols as carbon source. Kekkaku 46:197-202.

21. Tsukamura, M., S. Mizuno, and H. Murata. 1975. Numerical taxonomy study of the taxonomic position of Nocardia rubra reclassified as Gordona lentifragmenta Tsukamura nom.nov. Int. J. Syst. Bacteriol. 25:377-382.

22. Tsukamura, M., S. Mizuno, H. Murata, and T. Oshima. 1974. Acid phosphatase activity of mycobacteria. Iryo 28:11-14.

23. Wayne, L. G., J. R. Doubek, and R. L. Russell. 1964. Classification and identification of mycobacteria. I. Tests employing Tween 80 as substrate. Am. Rev. Resp. Dis. 90:588-597. 